\title{
Pengaruh Tarif Pajak, Pemahaman Perpajakan, dan Sanksi Perpajakan Terhadap Kepatuhan Wajib Pajak UMKM
}

\author{
Luh Putu Gita Cahyani ${ }^{1}$ \\ Naniek Noviari ${ }^{2}$ \\ ${ }^{1,2}$ Fakultas Ekonomi dan Bisnis Universitas Udayana (Unud), Bali, Indonesia \\ e-mail: gitacahyani9774@gmail.com
}

\begin{abstract}
ABSTRAK
Usaha Mikro, Kecil dan Menengah (UMKM) merupakan salah satu sektor yang berpotensi memberikan sumbangsih terhadap penerimaan pajak Negara. Kepatuhan wajib pajak UMKM masih sangat rendah, khususnya kepatuhan wajib pajak UMKM yang terdaftar di KPP Pratama Singaraja pada tahun 2015-2017 belum mencapai 50\%. Tujuan penelitian ini adalah untuk menguji pengaruh tarif pajak, pemahaman perpajakan dan sanksi perpajakan terhadap kepatuhan wajib pajak UMKM. Teori yang digunakan dalam penelitian ini adalah theory of planned behavior. Sebanyak 100 Wajib Pajak Orang Pribadi UMKM dipilih menjadi responden dengan menggunakan rumus slovin. Metode penentuan sampel pada penelitian ini adalah accidental sampling dan teknis analisis data penelitian ini menggunakan analisis regresi linier berganda. Hasil penelitian menunjukkan bahwa tarif pajak, pemahaman perpajakan dan sanksi perpajakan berpengaruh positif terhadap kepatuhan wajib pajak UMKM baik secara simultan maupun parsial.

Kata kunci: Tarif pajak, pemahaman perpajakan, sanksi perpajakan, kepatuhan wajib pajak UMKM
\end{abstract}

\begin{abstract}
Micro, Small and Medium Enterprises (SME's) are one sector that has the potential to contribute to state tax revenue. Taxpayer compliance sector SME's is very low, especially taxpayer compliance UMKM registered at KPP Pratama Singaraja in 2015-2017 has not reached 50\%.The purpose of this study was to test of tax rates, understanding taxation and tax sanctions on SMEs taxpayer compliance. The theory used in this study is the theory of planned behavior. Based on the population, the sample in this study is 100 SMEs taxpayer were selected as respondents using the Slovin formula. The method of determining the sample in this study is accidental sampling and technical data analysis of this study using multiple linear regression analysis. The results show that the tax rate, understanding of taxation and taxation sanctions have a positive effect on SMEs taxpayer compliance.
\end{abstract}

Keywords: Tax rate, understanding of taxation, taxation sanctions, SMEs taxpayer compliance

\section{PENDAHULUAN}

Pajak merupakan salah satu target utama pemerintah yang dijadikan sumber pendapatan negara. Pemerintah mulai gencar mencari sektor-sektor yang berpotensi dapat meningkatkan penerimaan pajak. Sejak tahun 2013 pemerintah 
mulai menyoroti sektor UMKM di Indonesia yang mulai tumbuh dengan pesat. Langkah awal yang pemerintah lakukan untuk meningkatkan penerimaan pajak sektor UMKM dengan menetapkan tarif pajak final UMKM sebesar 1\% pada PP No 46 Tahun 2013. Penetapan tarif 1\% tersebut berjalan tidak sesuai dengan harapan karena beberapa wajib pajak UMKM yang tidak membayar pajak setiap bulannya. Tingkat kepatuhan wajib pajak UMKM masih terbilang rendah dan belum mencapai target penerimaan pajak negara. Rendahnya kepatuhan wajib pajak UMKM tentu saja menjadi permasalahan setiap tahunnya di Bali, terutama di Kabupaten Buleleng. Pada tahun 2013, saat pertama kali diterapkannya tarif 1\% tersebut, KPP Pratama Singaraja mencatat penerimaan pajak terendah di Provinsi Bali. Hingga Tahun 2017, masalah rendahnya kepatuhan pajak di Kabupaten Buleleng masih dialami hingga saat ini. Jumlah WP OP UMKM yang tercatat di KPP Pratama Singaraja per Desember 2017 mencapai 4.093 wajib pajak orang pribadi UMKM. Peningkatan jumlah UMKM tersebut tidak sejalan dengan kesadaran wajib pajak UMKM dalam memenuhi kewajibannya untuk membayar pajak. Kondisi tersebut dapat dicantumkan dalam data wajib pajak orang pribadi UMKM pada Tabel 1.

Tabel 1.

Data Penerimaan WP OP UMKM KPP Pratama Singaraja Tahun 2015-2017

\begin{tabular}{lccc}
\hline Keterangan & 2015 & 2016 & 2017 \\
\hline $\begin{array}{l}\text { Target Penerimaan dari Wajib Pajak } \\
\text { Orang Pribadi UMKM }\end{array}$ & 17.845 .236 .523 & 21.491 .848 .378 & 18.757 .895 .245 \\
Realisasi Penerimaan dari Wajib & & & \\
Pajak Orang Pribadi UMKM & 5.716 .638 .107 & 7.132 .580 .715 & 8.569 .054 .415 \\
\% Kepatuhan Wajib Pajak Orang & & & \\
Pribadi UMKM & 32.03 & 33.19 & 45.68 \\
\hline Sumber: KPP Pratama Singaraja, 2018 & & &
\end{tabular}


Berdasarkan Tabel 1, terlihat bahwa realisasi penerimaan pajak wajib pajak orang pribadi sektor UMKM tidak pernah mencapai target secara keseluruhan. Tabel 1 menunjukkan tingkat kepatuhan wajib pajak tahun 2015 berada pada persentase $32,03 \%$, kemudian mengalami sedikit peningkatan pada tahun 2016 yaitu berada pada persentase 33,19\%. Pada tahun 2017, kembali terjadi kenaikan hingga mencapai kisaran 45,68\%. Presentase kepatuhan pajak telah mengalami peningkatan hingga tahun 2017, namun capaian kepatuhan pajak tersebut masih rendah karena belum mencapai $50 \%$ dan masih sangat jauh dari target penerimaan pajak yang ditetapkan. Rendahnya kepatuhan wajib pajak UMKM tersebut mendorong pemerintah untuk membuat peraturan baru pada Juli 2018 bahwa tarif PPh Final UMKM diturunkan sebesar 0,5\% dan perubahan tersebut tertuang dalam Peraturan Pemerintah No 23 Tahun 2018. Tentunya dengan penurunan tarif tersebut dapat memberikan keadilan bagi wajib pajak dan tidak mengakibatkan kerugian bagi wajib pajak yang memiliki omzet yang rendah.

Tarif pajak adalah persentase yang digunakan sebagai dasar dalam menghitung jumlah pajak yang harus disetor. Penurunan tarif Final UMKM dari $1 \%$ menjadi $0,5 \%$ menunjukkan bahwa tarif pajak merupakan salah satu faktor yang memengaruhi kepatuhan WP UMKM.

Faktor lainnya yang dapat memengaruhi kepatuhan pajak adalah pemahaman perpajakan. Dewasa ini salah satu kelemahan wajib pajak UMKM adalah rendahnya pemahaman wajib pajak mengenai peraturan perpajakan. Kelemahan inilah yang bisa memengaruhi wajib pajak UMKM dalam memenuhi 
kewajiban perpajakannya. Ada beberapa perubahan terkait peraturan pemerintah no 23 tahun 2018 tentang wajib pajak UMKM. Tentunya wajib pajak UMKM harus memiliki pemahaman yang baik terkait peraturan tersebut terutama tentang penurunan tarif final $0.5 \%$. Perubahan peraturan tersebut akan memudahkan wajib pajak UMKM dalam melakukan perhitungan dan pembayaran pajak setiap bulannya.

Sanksi pajak adalah faktor lain yang dapat memengaruhi kepatuhan wajib pajak. Mardiasmo (2018: 86-88) menyebutkan sanksi perpajakan ialah suatu jaminan atas ketentuan perundang-undangan perpajakan dapat dipatuhi atau dijalani. Sanksi yang dikenakan diharapkan bisa meningkatkan kesadaran wajib pajak dalam memenuhi kewajiban perpajakannya. WP OP UMKM dapat patuh dalam membayar pajak apabila terdapat sanksi pajak yang tegas. Adanya sanksi pajak tersebut akan menumbuhkan niat WP OP UMKM dalam memenuhi kewajiban perpajakan setiap bulan.

Berdasarkan penjabaran latar belakang tersebut, maka peneliti ingin meneliti pengaruh tarif pajak, pemahaman perpajakan, dan sanksi perpajakan terhadap kepatuhan wajib pajak UMKM.

Berdasarkan penjelasan yang terdapat pada latarbelakang tersebut, jadi rumusan masalah pada penelitian kali ini yaitu; a) Apakah tarif pajak memengaruhi kepatuhan wajib pajak UMKM?; b) Apakah pemahaman perpajakan memengaruhi kepatuhan wajib pajak UMKM?; c) Apakah sanksi perpajakan memengaruhi kepatuhan wajib pajak UMKM? 
Terkait dengan rumusan masalah yang terdapat pada penelitian ini, beberapa tujuan yang ingin didapatkan yaitu: a) mendapatkan bukti empiris dari pengujian pengaruh tarif pajak terhadap kepatuhan wajib pajak UMKM; b) mendapatkan bukti empiris dari pengujian pengaruh pemahaman perpajakan terhadap kepatuhan wajib pajak UMKM; c) mendapatkan bukti empiris dari pengujian pengaruh sanksi perpajakan terhadap kepatuhan wajib pajak UMKM.

Adapun manfaat teoritis dan praktis yang bisa didapat yaitu; 1) Manfaat teoritis, penelitian ini dapat mendukung theory of planned behavior terkait hasil empiris dari penelitian ini dan pengujian ini diharapkan agar dapat meningkatkan wawasan serta ilmu pengetahuan sehingga dapat memberi konstribusi untuk pengembangan ilmu khususnya ekonomi maupun akuntansi yang berkaitan tentang perpajakan; 2) Manfaat praktis, penelitian ini dapat memperluas ilmu pengetahuan penulis maupun pembaca mengenai faktor-faktor yang memengaruhi wajib pajak UMKM untuk memenuhi kewajiban perpajakannya, dan dapat digunakan sebagai bahan informasi dan perluasan untuk penelitian selanjutnya tentunya terkait dengan pajak UMKM.

Theory of Planned Behavior (TPB) merupakan teori mengenai perilaku individu yang dipengaruhi oleh niat individu terhadap perilaku tertentu. Niat sesorang ditentukan oleh sikap (Behavioral belief), norma subjektif (Normatif belief), dan kontrol perilaku (Sulistiyani \& Harwiki, 2016). Menurut teori ini, perilaku individu dalam masyarakat berada di bawah pengaruh faktor-faktor tertentu yang berasal dari alasan tertentu dan muncul dengan cara yang terencana. Teori ini mempelajari perilaku manusia terutama terkait minat seseorang, 
menyediakan suatu kerangka untuk mempelajari sikap individu terhadap perilaku serta dapat memprediksi berbagai jenis perilaku dengan akurasi tinggi melalui norma subjektif, kontrol perilaku, dan sikap (Ghouri, Khan, \& Abdul Kareem, 2016). Theory of Planned Behaviour ini memiliki tiga hal yang mempengaruhi niat individu yaitu Behavioral Belief merupakan keyakinan individu akan hasil dari suatu perilaku (outcome belief) dan evaluasi terhadap hasil dari keyakinan tersebut. Normative Belief merupakan keyakinan tentang harapan normatif individu dan motivasi untuk memenuhi harapan tersebut. Normative belief mengacu pada tekanan sosial yang dihadapi oleh individu untuk melakukan atau tidak melakukan sesuatu. Kontrol perilaku (Control belief) mengacu pada tingkatan kontrol atas pandangan individu untuk melakukan suatu tindakan. Secara spesifik, kontrol perilaku mengacu pada keyakinan tentang keberadaan hal-hal yang mendukung atau menghambat perilaku seseorang dan persepsi tentang seberapa kuat hal-hal yang mendukung dan menghambat perilakunya tersebut.

Teori Pengambilan keputusan adalah suatu pendekatan sistematis terhadap hakikat alternatif yang dihadapi dan mengambil tindakan yang menurut perhitungan merupakan tindakan yang paling cepat. Menurut Curtis R. Finch dan McGough (1982) dalam (Dewi dan Lely, 2018) pengambilan keputusan adalah suatu tindakan dalam memilih beberapa alternatif yang ada. Teori pengambilan keputusan pada penelitian ini berkaitan dengan pengetahuan wajib pajak akan manfaat yang diperoleh dari penetapan PP No 23 Tahun 2018 terkait penurunan 
tarif pajak UMKM sebesar $0,5 \%$ yang memiliki tujuan untuk meningkatkan motivasi wajib pajak UMKM untuk memenuhi kewajiban perpajakannya.

Berdasarkan Theory of Planned Behavior, besarnya tarif pajak berkaitan dengan normative belief yang merupakan harapan yang dipersepsikan satu orang atau lebih untuk menyetujui suatu perilaku dan memotivasi seseorang dalam mematuhi kewajibannya. Tarif pajak adalah persentase yang dipakai sebagai dasar dalam menghitung pajak terutang yang harus disetor. Besarnya tarif final UMKM saat ini ialah $0,5 \%$, penurunan tarif ini bertujuan untuk memberikan motivasi wajib pajak untuk mematuhi kewajibannya dalam membayar pajak dan memberikan keadilan bagi wajib pajak UMKM. Tarif pajak yang adil dan tidak memberatkan bagi WP UMKM dapat mendorongnya dalam mematuhi kewajiban perpajakan setiap bulan. Semakin adil tarif pajak yang pemerintah tetapkan, maka semakin tinggi pula kepatuhan WP UMKM untuk melaporkan penghasilan kepada admisnitrasi pajak. Berdasarkan hasil penelitian Ananda (2015) dan Julianto (2017) menyatakan bahwa tarif pajak memiliki pengaruh positif pada kepatuhan WP UMKM. Maka, hipotesis pertama yang dapat diambil yaitu.

$\mathrm{H}_{1:}$ Tarif pajak berpengaruh positif pada kepatuhan wajib pajak UMKM

Berdasarkan Teori Of Planned Behavior, pemahaman perpajakan terkait dengan behavioral belief menjelaskan bahwa sikap individu akan memengaruhi keinginan individu dalam bertindak dengan mengetahui hasil dari tindakan yang dilakukan individu tersebut. Teori ini memiliki pengaruh pemahaman Wajib Pajak terhadap niat mereka dalam mematuhi kewajiban perpajakannya. Tingkat pemahaman WP UMKM atas perpajakan dapat dinilai dari pemahaman dalam 
menghitung pajak terutang, membayar pajak dan melaporkan pajak terutang. Tingkat pemahaman yang tinggi dapat mendorong Wajib Pajak UMKM agar mematuhi dan melaksanakan kewajiban perpajakannya. Semakin tinggi pemahaman perpajakan yang dimiliki wajib pajak maka hal itu seiringan dengan semakin meningkat pula kepatuhan wajib pajak. Wahyuningsih (2016) mendapat hasil penelitiannya yaitu pemahaman perpajakan berpengaruh signifikan dan positif terhadap kepatuhan WP. Simpulan tersebut sesuai dengan Prajogo (2013) dan Julianto (2017) yang menyebutkan pemahaman perpajakan berpengaruh signifikan terhadap kepatuhan WP. Maka, hipotesis kedua yang dapat diambil yaitu.

$\mathrm{H}_{2}$ : pemahaman perpajakan berpengaruh positif pada kepatuhan wajib pajak UMKM

Variabel sanksi perpajakan ada kaitannya terhadap control belief yang memiliki arti keyakinan seseorang tentang keberadaan suatu hal yang menghambat atau mendukung perilaku individu tersebut. Berdasarkan teori pengambilan keputusan, pemberian sanksi yang berat adalah satu alternatif yang diharapkan dapat mengatasi ketidakpatuhan wajib pajak dalam pembayaran pajak terutang. Sanksi pajak ditetapkan bertujuan untuk memotivasi wajib pajak dalam mematuhi peraturan pajak yang ditetapkan. Wajib pajak bertindak patuh apabila mereka memiliki persepsi bahwa akan dikenai sanksi yang berat jika melakukan pelanggaran. Hal tersebut sesuai dengan hasil penelitian Zulhaj (2016) bahwa sanksi pajak berpengaruh positif terhadap kepatuhan pajak. Hasil itu didukung adanya penelitian sebelumnya oleh Mangoting (2013) dan Prawagis (2016) bahwa 
sanksi pajak berpengaruh signifikan positif pada kepatuhan pajak. Maka, hipotesis ketiga yang dapat diambil yaitu.

$\mathrm{H}_{3}$ : Sanksi perpajakan berpengaruh positif pada kepatuhan wajib pajak UMKM.

\section{METODE PENELITIAN}

Jenis penelitian berdasarkan tujuan dan sesuai dengan permasalahan tersebut yaitu penelitian kuantitatif dengan melakukan pengolahan data dan penyajian data. Lokasi penelitian berlokasi di KPP Pratama Singaraja. Peneliti melakukan penelitian di KPP Pratama Singaraja karena persentase kepatuhan WP OP sektor UMKM masih rendah dan belum mencapai 50\%. Objek pengujian ini terdiri dari kepatuhan WP UMKM, tarif pajak, pemahaman perpajakan dan sanksi perpajakan.

Populasi penelitian ini sebanyak 4.093 WP OP UMKM yang terdapat di KPP Pratama Singaraja per Desember 2017. Daftar klasifikasi jumlah WP OP UMKM berdasarkan jenis usaha pada Kantor Pajak Pratama Singaraja.

Tabel 2.

Klasifikasi Jumlah WP OP UMKM Berdasarkan Jenis Usaha pada KPP Pratama Singaraja

\begin{tabular}{|c|c|c|}
\hline No & Jenis Usaha & Jumlah Wajib Pajak \\
\hline 1 & Perdagangan & 2.395 \\
\hline 2 & Industri & 243 \\
\hline 3 & Jasa & 1.455 \\
\hline & 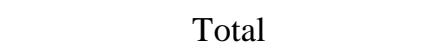 & 4.093 \\
\hline
\end{tabular}

Penentuan sampel pengujian ini menggunakan Metode accidental sampling dengan rumus slovin. Kriteria yang dipilih menjadi responden pengujian ini adalah WP OP UMKM di Kantor KPP Pratama Singaraja yang memiliki omzet 
tidak melebihi 4,8 Miliar. Sampel pengujian ini diperoleh atas dasar perhitungan dengan rumus slovin (Siregar, 2013:33).

$$
n=\frac{N}{\left(1+N e^{2}\right)}
$$

Keterangan:

$\mathrm{n}=$ total sampel

$\mathrm{N}=$ total populasi

$\mathrm{e}=$ kesalahan yang ditolerir $(0,1)$

Perhitungan jumlah sampel:

$$
\begin{aligned}
& n=\frac{4.093}{\left(1+4.093(0,1)^{2}\right)} \\
& n=99,97 \\
& n=100 \text { (dibulatkan) }
\end{aligned}
$$

Total populasi $(\mathrm{N})$ adalah 4.093 dengan presentase kesalahan yang dapat ditolerir (e) ialah 1\%. Dalam menghitung sampel dengan rumus slovin, telah didapat jumlah sampel pada pengujian ini yaitu 100 WPOP UMKM yang terdapat pada KPP Pratama Singaraja Pada Tahun 2017. Penelitian kali ini memilih skala likert modifikasi yaitu dengan memberi nilai 4 bagi jawaban responden untuk skor tertinggi serta skala poin 1 bagi responden untuk skor terendah.

Metode accidental sampling digunakan untuk penentuan sampel pengujian ini. Adapun kriteria yang dipilih sebagai responden pada pengujian ini yaitu WP OP UMKM yang terdapat di KPP Pratama Singaraja dan memiliki omzet tidak melebihi 4,8 Miliar.

Metode dalam pengumpulan berbagai data dilakukan dengan cara disebarkannya kuesioner terhadap responden dilapangan. Teknik analisis yang digunakan antara lain uji deskriptif, uji valid dan reliabilitas, kamudian uji asumsi klasik, selanjutnya uji analisis regresi linear berganda, uji kelayakan model, koefisien determinasi serta uji hipotesis. Jenis data yang dipakai dalam pengujian 
ini adalah: 1) Data kualitatif yang merupakan suatu gambaran umum dari WPOP UMKM di KPP Pratama Singaraja; 2) Data kuantitatif, ialah data menyangkut kondisi kepatuhan WP OP UMKM di KPP Pratama Singaraja pada tahun 2017. Sumber data pengujian ini yaitu: 1) Data primer menggunakan kuesioner yang diberikan dan dijawab secara langsung oleh responden secara tertulis. 2) Data sekunder, dari jurnal terkait penerimaan pajak UMKM di Provinsi Bali dan data yang diperoleh dari KPP Pratama Singaraja terkait tingkat kepatuhan Wajib Pajak Orang Pribadi UMKM Tahun 2015-2017, sejarah KPP Pratama Singaraja, Visi Misi dan Struktur Organisasi KPP Pratama Singaraja

\section{HASIL DAN PEMBAHASAN}

Responden yang terdapat pada KPP Pratama Singaraja memiliki karakter atau identitas yang berbeda dalam melakukan pengisian kuesioner. Kuesioner yang disebarkan sebanyak 110 kuesioner melebihi dari jumlah sampel yang ditentukan yaitu sebesar 100 untuk menghindari kuesioner yang tidak memenuhi kriteria penelitian. Dari 110 jumah kuesioner yang disebar, terdapat 10 kuesioner yang tidak memenuhi kriteria penelitian dan 100 kuesioner dapat digunakan pada pengujian ini. Adapun karakteristik responden dalam pengujian ini terdapat pada Tabel 3 dibawah ini. 
Tabel 3.

Karakteristik Responden

\begin{tabular}{|c|c|c|c|}
\hline No & Karakteristik Responden & Frekuensi & $\begin{array}{c}\text { Jumlah Persentase } \\
(\%)\end{array}$ \\
\hline \multirow[t]{4}{*}{1} & Berdasarkan Jenis Kelamin & & \\
\hline & Laki-laki & 55 & 55 \\
\hline & Perempuan & 45 & 45 \\
\hline & Jumlah & 100 & 100 \\
\hline \multirow[t]{9}{*}{2} & Berdasarkan Pendidikan terakhir & & \\
\hline & SD & 1 & 1 \\
\hline & SMP & 4 & 4 \\
\hline & SMA & 27 & 27 \\
\hline & DIPLOMA & 26 & 26 \\
\hline & S1 & 35 & 35 \\
\hline & S2 & 7 & 7 \\
\hline & S3 & 0 & 0 \\
\hline & Jumlah & 100 & 100 \\
\hline \multirow[t]{4}{*}{3} & Berdasarkan Kepemilikan NPWP & & \\
\hline & Ya & 100 & 100 \\
\hline & Tidak & 0 & 0 \\
\hline & Jumlah & 100 & 100 \\
\hline \multirow[t]{6}{*}{4} & Berdasarkan Jenis Usaha & & \\
\hline & Perdagangan & 51 & 51 \\
\hline & Jasa tidak sehubungan pekerjaan bebas & 42 & 42 \\
\hline & Jasa sehubungan pekerjaan bebas & 0 & 0 \\
\hline & Industri & 7 & 7 \\
\hline & Jumlah & 100 & 100 \\
\hline \multirow[t]{4}{*}{5} & Berdasarkan Omzet & & \\
\hline & 4,8 Miliar & 100 & 100 \\
\hline & 4,8 Miliar & 0 & 0 \\
\hline & Jumlah & 100 & 100 \\
\hline \multirow[t]{4}{*}{6} & Berdasarkan Jenis Kepemilikan & & \\
\hline & Pribadi & 100 & 100 \\
\hline & Badan & 0 & 0 \\
\hline & Jumlah & 100 & 100 \\
\hline
\end{tabular}

Sumber: Data diolah, 2018

Berdasarkan Tabel 3 tersebut dapat dilihat bahwa karakteristik responden

dikelompokkan berdasarkan jenis kelamin, pendidikan terakhir, memiliki NPWP, jenis usaha, omzet dan jenis kepemilikan. 
Uji validitas dalam penelitian ini dilakukan untuk mengetahui validitas instrumen dengan nilai koefisien korelasinya $\geq 0,3$ (Sugiyono, 2017:172). Hasil uji validitas penelitian ini dicantumkan dalam Tabel 4.

Tabel 4.

Uji Validitas Instrumen

\begin{tabular}{cc} 
Variabel & Korelasi Pearson \\
\hline Tarif Pajak $\left(\mathrm{X}_{1}\right)$ & 0,506 \\
\hline Pemahaman Perpajakan $\left(\mathrm{X}_{2}\right)$ & 0,741 \\
& 0,829 \\
& 0,829 \\
Kepatuhan Wajib Pajak UMKM (Y) & 0,780 \\
& 0,617 \\
& 0,602 \\
& 0,602 \\
& 0,837 \\
& 0,771 \\
& 0,691 \\
& 0,817 \\
& 0,816 \\
& 0,536 \\
& 0,703 \\
& 0,835 \\
& 0,511 \\
& 0,818 \\
& 0,875 \\
& 0,769 \\
& 0,754 \\
& 0,794 \\
\hline
\end{tabular}

Sumber: Data diolah, 2018

Tabel 4 menunjukkan bahwa seluruh variabel yang akan digunakan dalam penelitian ini menghasilkan nilai korelasi lebih dari 0,30 yang berarti pernyataan yang terdapat pada kuesioner telah dinyatakan valid.

Uji reliabilitas dilakukan dengan melihat Cronbach Alpha yang menunjukkan sejauh mana alat ukur dapat diandalkan. Instrumen disebut reliabel 
apabila Nilai pada Alpha Cronbach adalah lebih dari atau setara 0,60. Berikut Hasil uji reliabilitas intrumen terdapat dalam tabel 5 dibawah ini.

Tabel 5.

Pengujian Reliabilitas Instrumen

\begin{tabular}{lc}
\hline \multicolumn{1}{c}{ Variabel } & Croncbach's Alpha \\
\hline Tarif Pajak & 0,793 \\
Pemahaman Perpajakan & 0,781 \\
Sanksi Perpajakan & 0,801 \\
Kepatuhan Wajib Pajak UMKM & 0,854 \\
\hline
\end{tabular}

Sumber: Data diolah, 2018

Berdasarkan Tabel 5 menunjukkan dari kelima variabel penelitian mempunyai Cronbach's Alpa diatas 0,60 maka instrumen pada kuesioner adalah reliabel.

Uji asumsi klasik diterapkan untuk mengetahui kelayakan dalam model regresi dan untuk mengetahui apakah dalam model regresi ditemukan pelanggaran asumsi klasik. Pengujian asumsi klasik pertama adalah uji normalitas dengan metode One Sample K-S. Apabila hasilnya dengan nilai signifikansi residual diatas nilai 0,05 jadi disebut data berdistribusi normal.

Tabel 6.

Uji Normalitas

\begin{tabular}{lc}
\hline & Residual Unstandardized \\
\hline $\mathrm{N}$ & 100 \\
Asymp.Sig.(2-tailed) & 0,171 \\
\hline Sumber:Data Diolah, 2018 &
\end{tabular}

Tabel 6 terkait uji normalitas tersebut memerlihatkan bahwa nilai Sig adalah $0,171>0,05$. Jadi data yang digunakan berdistribusi normal.

Uji multikolinearitas penting dilakukan untuk menilai ada tidaknya korelasi pada variabel bebas dalam model regresi. Hal tersebut dilakukan dengan membandingkan nilai tolerance melebihi $10 \%$ dan dengan melihat hasil Variance Inflation Factor dibawah 10. 
Tabel 7. Hasil Uji Multikolinearitas

\begin{tabular}{lccl}
\hline \multicolumn{1}{c}{ Variabel } & Tolerance & VIF & Keterangan \\
\hline $\begin{array}{l}\text { Tarif Pajak (X1) } \\
\begin{array}{l}\text { Pemahaman perpajakan } \\
\text { (X2) }\end{array}\end{array}$ & 0.923 & 1.083 & Bebas dari multikolinearitas \\
Sanksi perpajakan $(\mathrm{X} 3)$ & 0.937 & 1.067 & Bebas dari multikolinearitas \\
\hline Sumber: Data & 0.962 & 1.040 & Bebas dari multikolinearitas \\
\hline
\end{tabular}

Sumber: Data diolah, 2018

Tabel 7 diatas menunjukkan nilai tolerance pada setiap variabel melebihi $10 \%$ dan VIF tidak melebihi 10 artinya model regresi bebas dari multikolonieritas.

Uji statistik deskriptif bertujuan untuk menggambarkan karakteristik variabel penelitian yaitu nilai mean, minimum, maksimum,dan simpangan baku dengan $\mathrm{N}$ sejumlah 100. Hasil uji deskriptif ditampilkan pada bagian Tabel 8 berikut.

Tabel 8.

Uji Deskriptif

\begin{tabular}{lccccc}
\hline \multicolumn{1}{c}{ Variabel } & N & Min & Max & Mean & $\begin{array}{c}\text { Std. } \\
\text { Deviation }\end{array}$ \\
\hline Tarif Pajak (x1) & 100 & 12.00 & 20.00 & 16.14 & 2.084 \\
Pemahaman Perpajakan(x2) & 100 & 16.00 & 24.00 & 20.10 & 2.139 \\
$\begin{array}{l}\text { Sanksi Perpajakan(x3) } \\
\text { Kepatuhan Wajib Pajak UMKM }\end{array}$ & 100 & 10.00 & 20.00 & 17.37 & 2.419 \\
(x4) & 100 & 12.00 & 24.00 & 20.82 & 2.840 \\
\hline
\end{tabular}

Sumber: Data diolah, 2018

Penjabaran dari hasil uji statistic deskriptif pada Tabel 8 tersebut diatas adalah sebagai berikut;

Variabel tarif pajak mendapatkan angka minimum yaitu 12,00 kemudian angka maksimum yaitu 20,00. Nilai mean untuk variabel tarif pajak ialah sebesar 16,14 , serta terdapat penyimpangan baku sebesar 2,084 . 
Variabel independen yang kedua yaitu pemahaman perpajakan dengan nilai minimum yaitu 16,00 serta nilai maximum yaitu 24,00. Nilai mean pada variabel pemahaman perpajakan ialah 20,10 dengan standar deviasi sebesar 2,139.

Variabel independen yang ketiga yaitu sanksi perpajakan dengan nilai minimum adalah 10,00 serta nilai maximum yaitu 20,00 . Nilai mean pada variabel sanksi perpajakan adalah sebesar 17,37 dengan standar deviasi sebesar 2,419

Variabel dependen yaitu kepatuhan WP UMKM dengan nilai minimum yaitu 12,00 serta nilai maximum adalah 24,00. Nilai mean untuk variabel kepatuhan WP UMKM adalah sebesar 20,82 dengan standar deviasi sebesar 2,840 .

Uji heteroskedastisitas berguna untuk melihat apakah dterjadi ketidaksamaan varians dengan uji Glejser. Jika variabel bebas yang diteliti nilai signifikansinya diatas 0,05 pada nilai absolute residual, artinya bebas terhadap heteroskedastisitas. Hasil pengujian heteroskedastisitas tertuang didalam Tabel 9.

Tabel 9.

Hasil Uji Heteroskedastisitas

\begin{tabular}{lcc}
\hline & Variabel & Signifikan. \\
\hline Tarif Pajak (X1) & 0.439 \\
Pemahaman perpajakan (X2) & 0.733 \\
Sanksi perpajakan (X3) & 0.186 \\
\hline Sumber: Data diolah, 2018 &
\end{tabular}

Pada Tabel 9 terdapat hasil yaitu nilai signifikansi dari setiap variabel independen sebesar 0,$439 ; 0,733$ dan 0,186 yang artinya bebas dari heteroskedastisitas.

Setelah uji asumsi klasik terpenuhi, maka selanjutnya melakukan pengujian regresi linier berganda. Uji ini diterapkan untuk menguji seberapa jauh 
variabel bebas mempengaruhi variabel independen. Sehingga dapat memeroleh hasil uji yang ditunjukkan dalam Tabel 10.

Tabel 10.

Uji Analisis Linier Berganda

\begin{tabular}{lcccc}
\hline \multicolumn{1}{c}{ Variabel } & Unstandardized Beta & Std. Error & T hitung & $\begin{array}{l}\text { Signifikansi. } \\
\text { uji t }\end{array}$ \\
\hline Constant & 5.369 & 3.546 & 1.514 & 0.133 \\
Tarif Pajak (X1) & 0.268 & 0.132 & 2.026 & 0.046 \\
Pemahaman perpajakan (X2) & 0.292 & 0.128 & 2.284 & 0.025 \\
Sanksi perpajakan (X3) & 0.303 & 0.112 & 2.718 & 0.008 \\
\hline
\end{tabular}

Sumber: Data diolah, 2018

Berdasarkan pengujian regresi linier pada Tabel 10, dapat disimpulkan persamaan (Y) yaitu.

$$
Y=5,369+0.268 X_{1}+0.292 X_{2}+0.303 X_{3}+e
$$

Nilai konstanta menunjukkan besarnya nilai pada variabel dependen apabila variabel indenpenden adalah 0 . Konstanta bernilai 2,461 menunjukan arti jika variabel tarif pajak, pemahaman perpajakan dan sanksi perpajakan bernilai 0 (nol), maka tingkat kepatuhan wajib pajak UMKM cenderung meningkat sebesar 2,461 dengan nilai signifikasinya $<0,05$.

Nilai koefisien tarif pajak $\left(\mathrm{X}_{1}\right)$ 0,430 menunjukkan arti bahwa tarif pajak $\left(\mathrm{X}_{1}\right)$ memiliki hubungan positif pada kepatuhan wajib pajak UMKM. Artinya, jika variabel tarif pajak meningkat, maka kepatuhan wajib pajak UMKM akan cenderung meningkat sebesar 0,430 dengan asumsi variabel bebas lainnya konstan.

Nilai koefisien pemahaman perpajakan $\left(\mathrm{X}_{2}\right)$ 0,270 menunjukkan arti bahwa pemahaman perpajakan $\left(\mathrm{X}_{2}\right)$ memiliki hubungan positif pada kepatuhan wajib pajak UMKM. Artinya, jika variabel pemahaman perpajakan meningkat, maka 
kepatuhan wajib pajak UMKM akan cenderung meningkat sebesar 0,270 dengan asumsi variabel bebas lainnya konstan.

Nilai koefisien sanksi perpajakan $\left(\mathrm{X}_{3}\right)$ 0,323 menunjukkan arti bahwa sanksi perpajakan $\left(\mathrm{X}_{3}\right)$ memiliki hubungan positif pada kepatuhan wajib pajak UMKM. Artinya, jika variabel sanksi perpajakan meningkat, maka kepatuhan wajib pajak UMKM akan cenderung meningkat sebesar 0,323 dengan asumsi variabel bebas lainnya konstan.

Dalam pengujian ini jika hasil pengujian $\mathrm{F}$ menghasilkan signifikan $\mathrm{F}$ atau $\mathrm{P}$ value sebesar $<0,05$ maka hubungan seluruh variabel independen ialah signifikan memengaruhi kepatuhan Wajib Pajak UMKM di KPP Pratama Singaraja dan model regresi yang akan digunakan dikatakan layak untuk uji. Hasil dari uji simultan/uji F akan disajikan dalam Tabel 11 dibawah ini.

Tabel 11.

Uji Kelayakan Model (Uji F)

\begin{tabular}{|c|c|c|c|c|c|c|}
\hline & Model & Sum of Squares & Df & Mean Square & $\mathrm{F}$ & Signifikansi \\
\hline \multirow{3}{*}{1} & Regresi & 197.680 & 3 & 65.839 & 15.131 & $0.000^{\mathrm{b}}$ \\
\hline & Residual & 418.080 & 96 & 4.355 & & \\
\hline & Total & 615.760 & 99 & & & \\
\hline
\end{tabular}

Hasil pengujian F pada Tabel 10 menghasilkan nilai signifikan uji $\mathrm{F}$ sebesar 0,000 lebih rendah dibanding $5 \%(0,000<0,05)$. Hasil ini mengartikan bahwa model regresi linier yang diestimasi layak digunakan untuk menjelaskan pengaruh tarif pajak, pemahaman perpajakan dan sanksi perpajakan terhadap kepatuhan WP UMKM.

Koefisian determinasi menentukan seberapa besar kemampuan variansi variabel independen dalam menerangkan variansi dari variabel dependen. 
Tabel 12.

Uji Koefisien determinasi

\begin{tabular}{ccccc}
\hline Model & $\mathrm{R}$ & $R$ Square & $\begin{array}{c}\text { Adjusted } R \\
\text { Square }\end{array}$ & Std. Error \\
\hline 1 & $.567^{\mathrm{a}}$ & .321 & .300 & 2.08686 \\
\hline
\end{tabular}

Sumber:Data diolah, 2018

Hasil pengujian dalam Tabel 12 menghasilkan nilai Adjusted R Square yaitu 0.300 atau $30 \%$, memiliki arti bahwa sebesar $30 \%$ variansi kepatuhan wajib pajak UMKM dipengaruhi oleh variansi tarif pajak, pemahaman perpajakan, sanksi perpajakan. Sisanya sebesar $70 \%$ dijelaskan dengan variabel selain tiga variabel diatas yang tidak terdapat dalam pengujian ini.

Pengujian t digunakan untuk menunjukkan pengaruh semua variabel bebas secara parsial terhadap variabel terikat. Pengaruh tarif pajak, pemahaman perpajakan serta sanksi perpajakan secara parsial pada kepatuhan WP UMKM didapat dengan cara membandingkan nilai probabilitasnya dengan level of significance sebesar 5\%. Jika nilai probabilitas <level of significance 5\%, maka tarif pajak, pemahaman perpajakan dan juga sanksi perpajakan secara parsial berpengaruh pada kepatuhan WP UMKM.

Tabel 13.

Uji Hipotesis (Uji t)

\begin{tabular}{lcc}
\hline \multicolumn{1}{c}{ Variabel } & T hitung & Sig. \\
\hline (Constant) & 0.895 & 0.373 \\
Tarif Pajak (X1) & 4.154 & 0.000 \\
Pemahaman Perpajakan (X2) & 2.649 & 0.009 \\
Sanksi Perpajakan (X3) & 3.666 & 0.000 \\
\hline
\end{tabular}

Sumber:Data diolah, 2018

Berdasarkan hasil analisis Tabel 13 menunjukkan bahwa tarif pajak menghasilkan nilai signifikasi yaitu 0,000 dengan nilai t hitung sebesar 4,154. Signifikasi X1 yaitu 0,000 lebih rendah dengan $0,05(0,000<0,05)$. Jadi semakin 
adil tarif pajak yang diberikan, maka tingkat kepatuhan WP UMKM akan semakin meningkat.

Berdasarkan hasil analisis Tabel 13 menunjukan bahwa pemahaman perpajakan menghasilkan nilai signifikansi yaitu 0,009 dengan nilai t hitung sebesar 2.649. Signifikansi x2 yaitu 0,009 lebih rendah dibandingkan presentase kesalahan yang dapat diterima yaitu $5 \%$ atau $0,05(0,009<0,05)$ mengindikasikan bahwa H2 diterima. Hal tersebut menyimpulkan bahwa semakin tinggi pemahaman perpajakan, maka semakin meningkat kepatuhan WP UMKM.

Berdasarkan hasil analisis Tabel 13 menunjukan bahwa sanksi perpajakan menghasilkan nilai signifikansi yaitu 0,000 dengan nilai thitung sebesar 3,666. Signifikansi X3 yaitu 0,000 lebih rendah dengan 0,05. Hal tersebut menyimpulkan bahwa semakin tegas sanksi yang diberikan, maka semakin meningkat kepatuhan WP UMKM.

Berdasarkan pembahasan yang telah diuraikan terdapat beberapa implikasi penelitian yang dapat dimanfaatkan sebagai berikut.

Berkaitan dengan implikasi teoritis, pengujian ini menghasilkan simpulan mengenai pengaruh tarif pajak, pemahaman perpajakan serta sanksi perpajakan terhadap kepatuhan WP UMKM di KPP Pratama Singaraja. Hasil uji dalam pengujian ini menemukan hasil variabel bebas yaitu tarif pajak, pemahaman perpajakan dan sanksi perpajakan berpengaruh positif terhadap kepatuhan WP UMKM.

Pengujian ini mendukung theory of planned behavior yaitu kepatuhan wajib pajak dipengaruhi oleh niat wajib pajak itu sendiri dalam mengambil tindakan 
untuk patuh terhadap kewajiban perpajakan. Pengujian ini juga mendukung teori pengambilan keputusan yaitu patuh atau tidaknya wajib pajak tergantung dari berbagai alternatif yang akan dipilihnya untuk mengambil keputusan.

Dalam implikasi secara praktis, pengujian ini dapat digunakan sebagai motivasi bagi pemerintah, dirjen Pajak, dan KPP Pratama Singaraja untuk dapat meningkatkan sosialisasi terkait penurunan tarif pajak UMKM, sanksi yang dapat dikenai oleh wajib pajak UMKM serta sosialisasi terkait peraturan baru yaitu PP No 23 Tahun 2018. Selain itu, KPP Pratama Singaraja diharapkan dapat memberikan segala informasi yang diperlukan wajib pajak untuk meningkatkan kepatuhan wajib pajak UMKM. Bagi peneliti selanjutya, pengujian ini diharapkan dapat menjadi bahan rujukan untuk menambah informasi yang diperlukan dan sebagai acuan dalam penelitian yang dilakukan.

\section{SIMPULAN}

Penelitian yang telah dilakukan ini untuk menguji pegaruh tarif pajak, pemahaman perpajakan serta sanksi perpajakan terhadap kepatuhan WP UMKM. Lokasi pengujian ini terdapat pada KPP Pratama Singaraja dengan mengambil 100 wajib pajak sebagai sampel dari 4.093 jumlah populasi keseluruhan. Berdasarkan hasil dan pembahasan, simpulan ini dapat diuraikan pada bagian berikut. a) Tarif pajak berpengaruh positif terhadap kepatuhan WP UMKM, b) Pemahaman perpajakan berpengaruh positif terhadap kepatuhan WP UMKM; c) Sanksi perpajakan berpengaruh positif terhadap kepatuhan WP UMKM. 
Berdasarkan pada simpulan tersebut, saran-saran yang ingin disampaikan kepada peneliti selanjutnya yaitu yaitu terkait koefisien determinasi (Adjusted $R^{2}$ ) penelitian ini sebesar 0,300 yang berarti variabilitas variabel dependen yang dapat dijelaskan oleh variabel independen hanya sebesar 30\%, sedangkan sisanya sebesar $70 \%$ dijelaskan oleh variabel lain di luar model penelitian maka penelitian selanjutnya dapat menambahkan variabel lain terutama faktor-faktor yang dapat memengaruhi kepatuhan wajib pajak UMKM. Variabel yang dapat ditambahkan terkait faktor yang dapat mempengaruhi kepatuhan wajib pajak UMKM seperti modernisasi sistem administrasi perpajakan, kesadaran wajib pajak, dan sosialisasi perpajakan. Hal ini diperuntukkan agar hasil dari penelitian berikutnya dapat digunakan secara lebih luas.

\section{REFRENSI}

Bashori, A. N. 2015. Pengaruh Persepsi Atas PP Nomor 46 Tahun 2013 Terhadap Kepatuhan Sukarela Wajib Pajak Yang Memiliki Peredaran Bruto Tertentu Pada Kantor Pelayanan Pajak Pratama Surabaya Rungkut. Jurnal Universitas Airlangga, 45, hal. 1-27.

Abdulsalam, Mas'ud. 2014. Tax Rate And Tax Compliance In Africa. European Journal of Accounting Auditing and Finance Research, 2 (3), hal. 22-30.

Adiasa, Nirawan. 2013. Pengaruh Pemahaman Peraturan Pajak Terhadap Kepatuhan Wajib Pajak Dengan Moderating Preferensi Risiko. Accounting Analysis Journal, 2 (3).

Ananda, Pasca. 2015. Pengaruh Sosialisasi Perpajakan, Tarif Pajak, Dan Pemahaman Perpajakan Terhadap Kepatuhan Wajib Pajak. Jurnal Perpajakan, 6 (2), hal.1-9.

Bashori, A. N. 2015. Pengaruh Persepsi Atas PP Nomor 46 Tahun 2013 Terhadap Kepatuhan Sukarela Wajib Pajak Yang Memiliki Peredaran Bruto Tertentu Pada Kantor Pelayanan Pajak Pratama Surabaya Rungkut. Jurnal Universitas Airlangga, 45, hal. 1-27. 
Bt, N., Rosiati, Y., Norul, R., Bt, S., \& Hassan. 2017. Tax Penalties And Tax Compliance Of Small Medium Enterprises (SMEs) In Malaysia. International Journal of Business, Economics and Law, 12 (1), hal. 81-91.

Candra, Kartika Kusuma. 2016. Pengaruh Kualitas Pelayanan Pajak, Pemahaman Peraturan Perpajakan Serta Sanksi Perpajakan Terhadap Kepatuhan Wajib Pajak Orang Pribadi Dalam Membayar Pajak Tahun 2014. Skripsi Jurusan Akuntansi Pada Fakultas Ekonomi Universitas Negeri Yogyakarta.

Chebusit, C., Namusonge, G. S., Biraori, O. E., \& Kipkoech, E. C. 2014. Factors Affecting Tax Compliance Among Small and Medium Enterprises in Kitale. International Journal of Recent Research in Commerce Economics and Management (IJRRCEM), 1(3), hal. 60-75.

Daniel, Akubo. 2016. Tax Compliance Behaviour Of Small Scale Enterprises In Bassa Local Government Area Of Kogi State. Journal of Good Governance and Sustainable Development in Africa (JGGSDA), 3(1), hal. 58-72.

Dewi, Luh Putu Santi Krisna dan Lely, Ni Ketut Aryani Merkusiwati. 2018. Pengaruh Kesadaran Wajib Pajak, Sanksi Perpajakan, E-Filing, dan Tax Amnesty Terhadap Kepatuhan Pelaporan Wajib Pajak. E-Jurnal Akuntansi Universitas Udayana, 22 (2), hal. 1626-1655

Dlamini, Banele. 2017. Determinants of Tax Non-Compliance among Small and Medium Enterprises in Zimbabwe. Journal of Economics and Behavioral Studies, 9(4), hal. 242-250.

Fauzia, Mutia. 2018. Sri Mulyani Akui Penerimaan Pajak UMKM Masih Rendah. https://ekonomi.kompas.com/read/2018/07/14/164924926/sri-mulyani-akuipenerimaan-pajak-umkm-masih-rendah. Diakses 5 September 2018.

Fikri, Ahmad. 2018. Penerimaan Pajak 2017 Mencapai Rp. 1.151 Triliun. https://www.republika.co.id/berita/ekonomi/keuangan/18/01/05/p22ntk383penerimaan-pajak-2017-mencapai-rp-11511-triliun. Diakses 5 September 2018.

Gberegbe, F. B., \& Umoren, A. O. 2017. The Perception of Tax Fairness and Personal Income Tax Compliance of Smes in Rivers State. Journal of Research in Business and Management University Of Uyo Uyo, 5 (2), hal. $40-51$.

Ghouri, A. M., Khan, N. R., \& Abdul Kareem, O. B. 2016. Improving Employees Behavior through Extension in Theory of Planned Behavior: A Theoretical Perspective for SMEs. International Journal of Business and Management, 
11, hal. 196-213.

Ghozali, Imam. 2016. Aplikasi Analisis Multivariate dengan Program IBM SPSS 2003. In IBM SPSS 2003, pp. 52.

Gitaru, Kelvin. 2016. The Eff ect of Taxpayer Education on Tax Compliance in Kenya.( a case study of SME's in Nairobi Central Business District. Journal Economy University of Nairobi, 7(5), hal. 79-89.

Herryanto, M., \& Toly, A. A. 2013. Pengaruh kesadaran wajib pajak, kegiatan sosialisasi perpajakan, dan pemeriksaan pajak terhadap penerimaan pajak penghasilan di KPP Pratama Surabaya Sawahan. Tax and Accounting Review, 1(1), hal. 125-133.

Huda, Ainil. 2015. Pengaruh Persepsi Atas Efektifitas Sistem Perpajakan, Kepercayaan, Tarif Pajak Dan Kemanfaatan NPWP Terhadap Kepatuhan Membayar Pajak. Jom FEKON, 2 (2), hal. 1-15.

Julianto, A. 2017. Pengaruh Tarif, Sosialisasi serta Pemahaman Perpajakan terhadap Kepatuhan Wajib Pajak UMKM di Kota Semarang. Jurnal Ekonomi, 7 (1), hal. 67-76.

Kalsum, U., Gusnardi, \& Haryana, G. 2016. Pengaruh Pemahaman Perpajakan dan Kesadaran Wajib Pajak Terhadap Kepatuhan Wajib Pajak UMKM di Kota Pekanbaru. Jurnal Ekonomi Universitas Riau, 8(1).

Kundalini, Pertiwi. 2016. Pengaruh Kesadaran Wajib Pajak Dan Pelayanan Pegawai Pajak Terhadap Kesadaran Wajib Pajak. Jurnal Provita, 3 (1), hal. $1-13$.

Kusbandiyah, A. 2013. Pengaruh Persepsi PP Nomor 46 Tahun 2013 Terhadap Kepatuhan Sukarela Wajib Pajak Yang Memiliki Peredaran Bruto Tertentu Pada Kantor Pelayanan Pajak Pratama Purwokerto. Jurnal Ekonomi, 14 (2), hal. 107-125.

Kusmuriyanto, \& Susmiatun. 2014. Pengaruh Pengetahuan Perpajakan, Ketegasan Sanksi Perpajakan, dan Keadilan Perpajakan terhadap Kepatuhan Wajib Pajak UMKM di Kota Semarang. Accounting Analysis Journal, 3 (3), hal. 378-386.

Kuug, S. N. 2015. Factors Influencing Tax Compliance Of Small And Medium Enterprises In Ghana. Journal of Accounting Decision, 10 (2).

Mangoting, A. O. F. dan Y. 2013. Pengaruh Kualitas Pelayanan Petugas Pajak, Sanksi Perpajakan dan Biaya Kepatuhan Pajak Terhadap Kepatuhan Wajib Pajak UMKM. Tax \& Accounting Review, Vol. 1, 18-27. 
Manual, V., \& Xin, A. Z. 2016. Impact of Tax Knowledge, Tax Compliance Cost, Tax Deterrent Tax Measures towards Tax Compliance Behavior: A survey on Self-Employed Taxpayers in West Malaysia. Electronic Journal of Business and Management, 1, hal. 56-70.

Mardiasmo. 2018. Perpajakan Edisi Terbaru 2018. Yogyakarta: ANDI.

Mustikasari, E. 2014. Pengaruh Persepsi Atas PP Nomor 46 Tahun 2013 Terhadap Kepatuhan Sukarela Wajib Pajak Yang Memiliki Peredaran Bruto Tertentu Pada Kantor Pelayanan Pajak Pratama Surabaya Rungkut. Jurnal Ekonomi Universitas Airlangga, 3 (2), hal. 1-27.

Mutia, Sri Putri Tita. 2014. Pengaruh Sanksi Perpajakan, Kesadaran Perpajakan, Pelayanan Fiskus, dan Tingkat Pemahaman terhadap Kepatuhan Wajib Pajak Orang Pribadi. e-Perpajakan, hal. 1-30.

Natalia, Amanda dan Budiasih, I Gusti Nyoman. 2017. Analisis Penerapan Peraturan Pemerintah No. 46 Tahun 2013 Terhadap Tingkat Penerimaan Pajak Di Kpp Pratama Badung Selatan. E-Jurnal Akuntansi Universitas Udayana, 19 (3), hal. 1861-1886

Oladipupo, A. O., \& Obazee, U. 2016. Tax knowledge, Penalties and Tax Compliance in Small and Medium Scale Enterprises in Nigeria. Journal of Accounting and Business, 8 (1), hal. 1-9.

Peraturan Menteri Keuangan Nomor 192/PMK.03/2007 tentang Tata Cara Penetapan Wajib Pajak Dengan Kriteria Tertentu Dalam Rangka Pengembalian Pendahuluan Kelebihan Pembayaran Pajak

Prajogo, J. R. 2013. Pengaruh Tingkat Pemahaman Peraturan Pajak Wajib Pajak,Kualitas Pelayanan Petugas Pajak dan Persepsi atas Sanksi Perpajakan Terhadap UMKM Di Wilayah Sidoarjo. Tax \& Accounting Review, 3 (2), hal. $1-12$.

Prawagis, F. D. 2016. Pengaruh Pemahaman Atas Mekanisme Pembayaran Pajak, Persepsi Tarif Pajak Dan Sanksi Pajak Terhadap Kepatuhan Wajib Pajak UMKM (Studi Pada Wajib Pajak Yang Terdaftar di KPP Pratama Batu). Jurnal Perpajakan, 10 (1), hal. 1-8.

Pukelini, Violeta. 2016. Tax Behaviour: Assessment Of Tax Compliance In European Union Countries. Journal Economy, 95 (2).

Purnamawati, G. A., \& Sinarwati, N. K. 2017. Kepatuhan Wajib Pajak Usahawan Atas Penerapan Peraturan Pemerintah Nomor 46 Tahun 2013 (Studi Pada 
Kantor Pelayanan Pajak Pratama Singaraja ). E-Jurnal Akuntansi, 7 (1).

Ramdan, Andi Nurmansyah. 2017. Pengaruh Perubahan Tarif, Metode Penghitungan Dan Modernisasi Sistem Pajak Terhadap Kepatuhan Wajib Pajak Umkm Dengan Keadilan Pajak Sebagai Variabel Moderasi Pada Umkm Di Kota Makassar. Skripsi Sarjana Akuntansi Pada Fakultas Ekonomi dan Bisnis Islam UIN Alauddin Makassar.

Rosella, Vina. 2015. Pengaruh Persepsi Atas PP Nomor 46 Tahun 2013 Terhadap Kepatuhan Wajib Pajak. Jurnal Ilmu dan Riset Akuntansi, 4 (9).

Rusmadi. 2017. Pengaruh Tax Amnesty Dan Sanksi Pajak Terhadap Kepatuhan Wajib Pajak. Jurnal iImiah Indonesia, 2 (3), hal. 124-133.

Setyorini, C. T. 2016. The Influence of Tax Knowledge, Managerial Benefit and Tax Socialization Toward Taxpayer's Willingness to Pay SME's Tax. Acta Universitatis Danubius, 12 (5), hal. 96-107.

Siregar, Sofyan. 2012. Metode Penelitian Kuantitatif. Jakarta: Kencana.

Sugiyono. 2017. Metode Penelitian Kuantitatif, Kualitatif, dan Kombinasi (Mixed Methods). Bandung: Alfabeta.

Suhendra, E. S. 2010. Pengaruh Tingkat Kepatuhan Wajib Pajak Badan Terhadap Peningkatan Penerimaan Pajak Penghasilan Badan. Jurnal Ekonomi Bisnis, 15 (1), hal. 58-65.

Suhendri, Diyat. 2015. Pengaruh Pengetahuan, Tarif Pajak, Dan Sanksi Pajak Terhadap Kepatuhan Wajib Pajak Orang Pribadi Yang Melakukan Kegiatan Usaha Dan Pekerjaan Bebas Di Kota Padang. Jurnal Akuntansi, 3 (1).

Sulistiyani, R., \& Harwiki, W. 2016. How SMEs Build Innovation Capability Based on Knowledge Sharing Behavior? Phenomenological Approach. Procedia - Social and Behavioral Sciences, 2 (9), hal. 741-747.

Undang-Undang Republik Indonesia Nomor 46 Tahun 2013 Tentang Pajak Penghasilan Atas Penghasilan Dari Usaha Yang Diterima Atau Diperoleh Wajib Pajak Yang Memiliki Peredaran Bruto Tertentu

Undang-Undang Republik Indonesia Nomor 23 Tahun 2018 Tentang Pajak Penghasilan Atas Penghasilan Dari Usaha Yang Diterima Atau Diperoleh Wajib Pajak Yang Memiliki Peredaran Bruto Tertentu

Utami, D. T., \& Kardinal. 2013. Pengaruh Kesadaran Wajib Pajak dan Sanksi Pajak Terhadap Kepatuhan Wajib Pajak Orang Pribadi pada Kantor Pelayanan Pajak Pratama Palembang Seberang Ulu. E-Jurnal Ekonomi, 2 (5), 
hal. 1-9.

Utaminingsrih, N. S., \& Ardyanto, A. A. 2014. Pengaruh Sanksi Pajak dan Pelayanan Aparat Pajak Terhadap Kepatuhan Wajib Pajak Dengan Preferensi Risiko Sebagai Variabel Moderating. Accounting Analysis Journal, 3 (1), hal. 361-369.

Wahabu, A. 2017. Examining Tax Compliance of Small and Medium-Sized. Thesis, University Of Cape Coast.

Wahyuningsih, T. 2016. Pengaruh Pemahaman Wajib Pajak, Tarif Pajak, Mekanisme Pembayaran Pajak Dan Kesadaran Wajib Pajak Terhadap Kepatuhan Wajib Pajak UMKM Bidang Mebel Di Surakarta. Skripsi. Fakultas Ekonomi dan Bisnis Islam Institut Agama Islam Negeri Surakarta

Wiranatha, Hadi. 2017. Pengaruh Pengetahuan Perpajakan, Modernisasi Sistem Administrasi Perpajakan, Tax Amnesty, Tingkat Penghasilan Pada Kepatuhan Wajib Pajak. E-Jurnal Akuntansi Universitas Udayana, 21 (3), hal. 2395-2424.

Zulhaj, Zaen. 2016. Pengaruh Persepsi Wajib Pajak Tentang Penerapan PP No. 46 Tahun 2013, Pemahaman Perpajakan, Dan Sanksi Perpajakan Terhadap Kepatuhan Wajib Pajak Usaha Mikro, Kecil, Dan Menengah Di Kota Yogyakarta. Jurnal Akuntansi, 5 (2), hal. 123-135. 